\title{
CityGuideTour Toruń - tourist application using augmented reality
}

\author{
Magdalena Węgrzyn, Albina Mościcka* \\ Military University of Technology \\ Faculty of Civil Engineering and Geodesy \\ 2, Gen. S. Kaliskiego Str., 00-908 Warsaw, Poland \\ e-mails: magdalenawegrzyn9@gmail.com, albina.moscicka@wat.edu.pl \\ Magdalena Węgrzyn: https://orcid.org/0000-0002-3173-4504 \\ Albina Mościcka: https://orcid.org/0000-0003-4673-3720
}

*Corresponding author: Albina Mościcka

Received: 15 March 2017 / Accepted: 14 August 2017

\begin{abstract}
The aim of the article is to show the possibilities of augmented reality in the field of geodesy and cartography. It discusses the concept of augmented reality, its origins and development, as well as areas of the existing applications. The practical functioning of augmented reality in the area of geodesy and cartography is presented on the example of an application developed for the tourist city of Torun, created with the use of CityGuideTour software. The principles of developing an application and the way it operates are also discussed. As a result, a fully operational bilingual application is available free of charge on the Web.
\end{abstract}

Key words: augmented reality, tourist application, CityGuideTour, Toruń

\section{Introduction}

Augmented reality (AR) is one of the fastest growing technologies today. Conditions for its development have become favourable together with the development of information technologies, both in software and hardware. In recent years, mobile devices allowing successful distribution of augmented reality have been developed. The multitude of these devices, their diversity and miniaturization as well as the endless possibilities of using them contributed to the presence of technology in the daily life of every human being. The potential of applications using augmented reality is only limited by the possibilities of the human imagination and the available equipment. Many ideas which have not yet been implemented into force and the potential of this technology can contribute to augmented reality soon becoming an integral part of human life. 
Augmented reality is nothing but a combination of two worlds: the real and virtual. This technology can be generally characterized as a system that allows for iteration with everything in the environment (Azuma, 1997). This system is based on information about the real objects in the vicinity of the observer. Next, additional objects generated by the computer are overlaid on the actual image seen in the camera of the mobile device,. Virtual objects can provide an unlimited range of content, including photos, descriptions, voice recordings, videos, maps, links to websites and many others. They have to be displayed in three-dimensional space. This means that each object is assigned a precise position in the space.

Augmented reality (AR) is often confused with virtual reality (VR), which does not create a new world, but modifies one that already exists (URL 1). What's more, virtual reality replaces the real world, through the image processed by the computer. In the case of augmented reality, the real world is only enriched and supplemented with additional information.

It would seem that augmented reality is a relatively young technology. However, the first work on the combination of two worlds - the real and the virtual - was started in the 1950s. American inventor Morton Heilig made a replica of the real world - Sensorama in 1962 (URL 2). The researcher developed a device that allowed the viewer to watch a three-dimensional colour image and sound reproduction. What's more, the machine had a movable seat which generated vibrations, and had the ability to generate wind and smell. Moreover, Heilig also developed a $3 \mathrm{D}$ camera that allowed for recording movies displayed by the Sensorama.

Among other contributors to the development of augmented reality (Langlotz at al., 2013) was American engineer Ivan Sutherland. He created a prototype of devices using technology AR and VR - a display mounted on the head (Head - mounted Display) (James, 2015; Sutherland, 1968). His position was determined by sound and a mechanical tracking system, and very simple graphics were placed on the real image in the camera.

At the turn of the sixties and seventies, Myron W. Krueger had been interested in augmented and virtual reality (Bryon, 2013). He was the creator of the "Glowflow" installation - a dark room with four transparent tubes, which changed colour when fluorescent molecules were added to them. Krueger was also the creator of the "Metplay" installation, consisting of a video transmission from two rooms and the possibility of modification of the visual effect arising as a result of overlapping images. The best-known Krueger venture was named "Videoplace". It was based on placing the participants in two different rooms, located at any distance apart. The images obtained from the rooms were superimposed over each other, and the participants were able to achieve the impression that they are next to each other. In addition, it was possible to touch the other person, and manipulate what was shown in the image. Each participant was equipped with a helmet and gloves to achieve the desired effects. 
In subsequent years, research on the use of augmented reality for the needs of the United States Air Force and NASA has been conducted. Thanks to this, in the early nineties, a system supporting aircraft production was developed (Rolland al., 1994). Using goggles fitted with a camera, it presented virtual cables together with their descriptions.

The first mobile AR system was developed by Steve Feiner in the form of a Tourist Machine (Aceti, 2013). The entire apparatus consisted of a rucksack in which a computer with a 3D accelerator, glasses acting as a display, a GPS system and a palmtop with a stylus used for communication with the computer were placed. The machine served as the source of information about the objects in the territory of Columbia University. The image, superimposed on the actual view in the camera, became brighter when the user was closer to the object. Looking at one point for a longer time resulted in the display of more information about the object.

In 1997, Ronald Azuma announced the expanded definition of augmented reality (Azuma, 1997) quoted above. Despite many attempts by other scientists, Azuma's definition won broad support and was accepted as the most correct.

The following years brought a series of new products that were undoubtedly a breakthrough in the field of augmented reality. Augmented reality browsers, such as Layar (URL 3), Wikitute (URL 4) and Junaio (Donovan, 2012) appeared on the market. The mobile applications, containing content from such areas of life as tourism, medicine, military, architecture, marketing, trade and entertainment were also developed (Furht, 2011). Each of them found widespread use and recognition of the users.

Augmented reality also won wide acclaim among fans of games and entertainment. It resulted in such applications as e.g. GolfScape GPS Rangefinder - showing the distance from golf courses, ARSoccer - which enabled kicking a virtual football, and many other games. In recent times, the most popular game using AR has been PokemonGO (URL 5). In just a few days, this game gained millions of users around the world. Admittedly, user encounters the augmented reality only when catching Pokémon, but in spite of this technology has attracted fans for which the AR is the main attraction, stimulating the imagination of the players.

Other available solutions in the field of augmented reality, among others, can show wind direction and atmospheric conditions in a particular place (see Breeze application), can show the place of crimes (Criminal Spot), can helps people with colour blindness (Danka), can show the virtual stars (Star Chart) and many others (Kaczor, 2011). A number of applications that use AR are currently in the concept phase. New ideas are constantly developed and are gaining wide recognition. The augmented reality market is huge and can be found in every area of human life.

Augmented reality is also developing in areas supported by geodesy and cartography, especially in the area of combining technical and historical knowledge (Mościcka and Wyszyński, 2016). One such area is tourism. Today, analogue maps and tourist guides are replaced by navigation and mobile applications. Undoubtedly, they facilitate 
visiting new places and have won the support of a wide audience. Applications using AR can show the users - in a useful and interesting way - a different kind of travel. What's more, applications are not only useful for determining the user's position or routing, but mainly for the location of tourist facilities and obtaining information about them. A perfect example is the PanoramaScope application (URL 6). It enables to add virtual information to the real image e.g. names of the peaks, which the tourist sees as well as their height.

Intended for people traveling by on the subway, the New York Nearest application (Kaczor, 2011) was created. Use of the application is very simple: the user simply points their mobile device down, and information which subway lines running under the user will appear on the screen. Keeping the phone oriented vertically, they can get information about distance to the subway lines.

Augmented reality is also useful in car navigation systems such as Wikitude Navigation (URL 7) or Follow Me (Kulka, 2012). In the former, the real image displayed on the device is combined with information such as direction of travel, and road signs. Follow Me, unlike Wikitude Navigation, comprises a virtual vehicle, which the user has to follow to reach a particular destination. An interesting solution is the CyberNavi system (Alabaster, 2013). It works thanks to a special display HUD placed between the driver's eyes and the window. CyberNavi devices present such information as speed limits, POI, street names. The system can also suggest an alternative route or remind about the road signs. The main goals of the solution proposed by the Pioneer Company is to increase safety on the roads. Using CyberNavi, the driver does not have to look away from the road to check the transit route for navigation.

The potential for use of augmented reality in geodesy and cartography seems to be high but is still in the development phase. It may be helpful during field work, to search for control points (Bielecka et al., 2014) and information about the objects in the database of the geodetic and cartographic documentation centre. Before starting the measurement, a surveyor working in the field, could use an application that uses augmented reality to obtain information about the area, identify both the geodetic points and boundary markers, as well as to compare the data from the office with current situation in the field. Moreover, the application would allow immediate contact with the appropriate geodetic and cartographic documentation centre. It could be also used as a navigation tool, thanks to which a surveyor could easily reach a specific object or point. Another solution, also useful in field work, could be an application that imposes network utilities on the image seen in the camera. At the moment, such solutions are only in the concept phase. However, taking into account the progressive development of both hardware and new applications, surveyors will probably very soon use mobile devices compatible with the augmented reality (Halik, 2012), instead of data in paper form, in their field work.

Taking the above into consideration, this article aims to present the opportunities offered by augmented reality in the field of geodesy and cartography, especially in developing tourist mobile application. This kind of solution - as well as mobile 
and interactive maps (Calka and Cahan, 2016) - is now replacing traditional maps and guides, but it uses typical cartographical data: thematic content related to the geographical space. The range of thematic data and application functionality is presented on the example of tourism; however, the presented solutions and capabilities can be used for many other geodetic purposes.

\section{Methodology}

The city of Torun was chosen as a test area to develop a tourist application with the use of AR. There are many interesting and famous historic buildings in the city, attracting many foreign tourists. Therefore, it was decided that the application would be developed in two languages: Polish and English.

It was assumed that the application would include the most important tourist sites in Torun, treated as points of interest (POI). Selection of the objects was based on the level of tourist attractiveness (popularity) of the object. A very important criterion was the availability (access) of the attractions to tourists. Therefore, the selection was focused on the objects located in the city centre, which the user is able to reach on foot. Selected sites are located in such as way as to make them reachable without deviating from the accepted main tourist route. Selected attractions include eight groups of objects: churches, museums, monuments, towers, townhouses, granaries, gates and others.

With the use of a mobile device, a virtual object in the form of a label is superimposed on each real tourist site. It was assumed that the label would contain elements enriching the real site by additional information about them. They are:

- descriptions

- practical information

- photos

- voice recordings.

It was assumed that descriptions of tourist attractions should contain the most important information about the object, which would be the most interesting to potential tourists. Therefore, descriptions contain historical data and include information about the past of the site, its date of creation, purpose, etc. It was also assumed that the descriptions should not bore the tourists, therefore, they should not be too long. It was decided that practical information would include data such as opening hours, ticket prices, the address, etc. Both descriptions and practical information contain data derived only from reliable sources, e.g. a tour desk, the official travel brochures of the city, or historical publications. This information was collected during the field interview in Torun and prepared in Polish and English.

It is not always possible to read the object description during the route or during a visit inside the buildings. It is often impossible to enjoy the delights of external or internal tourists site and read information about them at the same time. For that reason, voices reading information about the objects were recorded, and the user can 
play them during the tour. Voice recordings are based on the prepared descriptions of tourist attractions. Recordings in Polish were prepared with the use of Audacity software (URL 8). This is free software that allows not only for recording sounds, but also editing and processing. Voice recordings in English were prepared with the use of the Balabolka software (URL 9). This is a free software that allows users to convert text to speech. All resulting audio files are in the MP3 format and their length does not exceed one and a half minutes.

During the field interview, photographs of the objects were also taken. For any tourist facility, at least two pictures were taken. They were taken from different angles to allow the user to seamlessly identify the object, regardless of where they are located. In the case of tourist attractions, such as museums and churches, as far as it was possible, the interior was also photographed. All captured images were processed using the trial version of Adobe Photoshop CS6, which made it possible to improve parameters such as, among others, white balance, brightness, sharpening, colour balance and contrast. The Stamp tool was used to remove unwanted elements (e.g. people, cars) from the pictures. Due to the fact that many monuments are located on narrow streets, it was impossible to obtain a perfectly vertical photo of some objects. This effect is evident in buildings that are abnormally declivous. To correct these imperfections, an adaptive "wide angle" filter was used. It was used to draw a few lines, which are vertical lines of photo, frame the image respectively, and fill in the resulting defects.

Virtual elements placed against the background of the real image were located using a method involving the use of location services. This method relies on the fact that mobile devices with built-in sensors, e.g. compass, accelerometer, gyroscope, and GPS receiver, determine the location of both the user and the virtual objects using assigned coordinates $(\mathrm{X}, \mathrm{Y}, \mathrm{H})$, stored in a spatial database. In this solution, the main task of the system is the real-time operation.

To determine the geographical coordinates and altitude for each of the previously selected POI, two methods were used. The first one was to determine the position using the Google Maps service. Collected coordinates and heights were imported into the application, and then they were tested to check if the location of the object was correct. In order to verify the accuracy of the data obtained, a second method was used - the measurement of coordinates in the field. Results obtained from the two methods were compared in terms of proper display of the location of each object. In both methods, only the labels of larger objects were correctly displayed. Labels of smaller attractions, such as monuments, were displayed with some difficulties. It might appear that the point identified with the use of an orthophotomap is positioned correctly, while in fact, it was usually next to it. These problems were eliminated by using the second method of obtaining coordinates (measurement in the field), which allowed for the accurate determination of the position of the point.

The accuracy of location is extremely important when using the application. The user must be certain that the object observed by the camera of the mobile device has a successfully assigned label with information about it. The second method 
proved to be the more accurate and the coordinates obtained with it were taken as definitive. Additionally, attention was paid to the height at which the object labels are displayed. The adjustment of the labels over the object enabled positioning them in such a way that in case of close proximity to the tourist attractions, the labels do not overlap.

To develop applications for Torun, the CityGuideTour software, produced by the Polish company EnviroSolutions, was used (URL 10). The CityGuideTour software license was granted free of charge on the basis of an agreement between the company and the university. The CityGuideTour application acts as both informative and localization software, integrating data about the objects, as well as three-dimensional coordinates of the POI. This software enables the location in space of real objects and corresponding virtual elements and the gathering of and displaying information about them, as well as configuring the application in the manner established by the author.

CityGuideTour was enriched by a Wikitude library, which is one of the many available on the market. Thanks to this, the displayed content can be observed in the augmented reality module. The programming pack Wikitude SDK is a tool for commercial use, but it is possible to obtain a license for the educational version, by filling out the form on the manufacturer's in order to use it for non-commercial purposes for a specified period of time.

The configuration of all elements of the application was done in a JSON text file, which then was placed on the FTP server accessible to the application on the network.

The developed application was tested in the field. This enabled the detection and elimination of errors. Analysis of the application's functioning was performed using two mobile devices. This was to eliminate errors caused by possible irregularities arising from the operation of a particular model of equipment. Application performance was checked along the entire sightseeing route, and errors were corrected to ensure that the product introduced for public use has no defects and is fully functional.

\section{Results}

53 selected tourist facilities located in the center of Torun were selected as the thematic content of the application. The list of selected objects is presented in Table 1. For each object, practical information was gathered, descriptions of objects were prepared and voice recordings were made. Photos of objects were taken, and then retouched. An example of adjusting the quality of images is shown in Figure 1.

As a result of the work, the tourist application CityGuideTour Torun was created. It is available in the Google Play store for free public use by tourists and locals. The main application interface CityGuideTour Torun consists of a main menu (Figure 2b), which offers four basic options: Start a Tour, Favorites, Search, Visited. 
The basic functionality of the application is based on an item marked in the main menu as "Start a Tour". After selecting this option, the augmented reality mode is running. In accordance with the principle of operation of this technology, labels presenting attractions located near the user are placed on a real image which is seen in the mobile device camera (Figure 3). In the augmented reality operation mode, only a part of the description of the object and the distance from the user are seen. To receive complete information about the object, the real image view must be abandoned. After the "See more" option is selected, a description of the object, additional information about it and the image will be displayed (Figure 4). After an image is selected, a gallery of the object images will be presented.

Table 1. The list of selected tourist attractions (source: own work)

\begin{tabular}{|c|c|c|c|}
\hline Churches & $\begin{array}{l}\text { St. John's Cathedral } \\
\text { Former Holy Trinity Church } \\
\text { St. Stephen's Evangelical Lutheran } \\
\text { Church } \\
\text { Church of St. Jacob } \\
\text { The Holy Spirit Church } \\
\text { Church of St. Catherine } \\
\text { Marian Church }\end{array}$ & Museums & $\begin{array}{l}\text { Explorers' Museum } \\
\text { The Museum of Torun Gingerbread } \\
\text { The Live Gingerbread Museum } \\
\text { The House of Legends of Toruń } \\
\text { University Museum } \\
\text { Ethnographic Museum and open-air } \\
\text { museum } \\
\text { Copernicus House }\end{array}$ \\
\hline Monuments & $\begin{array}{l}\text { Copernicus Monument } \\
\text { Raftsman Statue } \\
\text { The Spanish Donkey of Torun }\end{array}$ & Granaries & $\begin{array}{l}\text { Swedish granary } \\
\text { Gothic granary } \\
\text { Late Renaissance granary }\end{array}$ \\
\hline Towers & $\begin{array}{l}\text { Gothic towers } \\
\text { Monstrance Tower } \\
\text { Cat's head tower } \\
\text { Dovecote Tower } \\
\text { Leaning Tower }\end{array}$ & Gates & $\begin{array}{l}\text { Sailors' Gate } \\
\text { Monastery Gate } \\
\text { Bridge Gate } \\
\text { Arc of Caesar }\end{array}$ \\
\hline $\begin{array}{l}\text { Tenement } \\
\text { houses }\end{array}$ & $\begin{array}{l}\text { Gothic tenement } \\
\text { Townhouse - Łazienna street } \\
\text { Fengers' Palace } \\
\text { House Under the Turk } \\
\text { Former Royal Pharmacy } \\
\text { Meissner Palace } \\
\text { Burgher Manor } \\
\text { The Palace of the Dąmbski Family } \\
\text { Artus Manor } \\
\text { The Eskens' House } \\
\text { Star House }\end{array}$ & Other & $\begin{array}{l}\text { City Hall } \\
\text { Marshal Office } \\
\text { Scientific Society } \\
\text { Former Jesuit College } \\
\text { Collegium Maius University of } \\
\text { Nicolaus Copernicus } \\
\text { Dybów Castle ruins } \\
\text { W. Dziewulski Planetarium } \\
\text { Wilam Horzyca Theater } \\
\text { Old bridge over the Vistula } \\
\text { Philadelphia Boulevard } \\
\text { The Centre of Contemporary Art. } \\
\text { Old Town Hall } \\
\text { Teutonic Castle }\end{array}$ \\
\hline
\end{tabular}


A standard application option, available from every screen, is the ability to change the settings (Figure 5a), such as the language and the buffer to search for tourist attractions. It is extremely important to determine the correct distance from displayed points, depending on where the observer is located. When the user is located right next to the object, the change of distance will allow for pinpointing the correct spot and prevent overlapping tags symbolizing objects in the distance.

During the development of the application, a specific buffer value was adopted for each type of tourist attraction. This was to enable the use of other options, such as determining which sites have already been visited. The user must be within a certain distance to be able to receive points for the places they have visited. This will allow user to participate in the ranking. The aim of this additional option am is to encourage the use of the product for entertainment. Moreover, information about the places visited and the ranking may be obtained by logging on to the software developer site.f.

The application also includes functions which complement the AR mode. One of them is the ability to access a list of tourist sites (Figure 5b), where users can find information on each tourist attraction without using the AR mode. Another option presents a list of sites added to the favourites and visited, as well as the chance to explore the city using AR mode. Choosing site from the list, in addition to obtaining information about it, the user can rate the site on a scale of one to five stars, to share the POI through social networking sites or email and add it to their favourites.

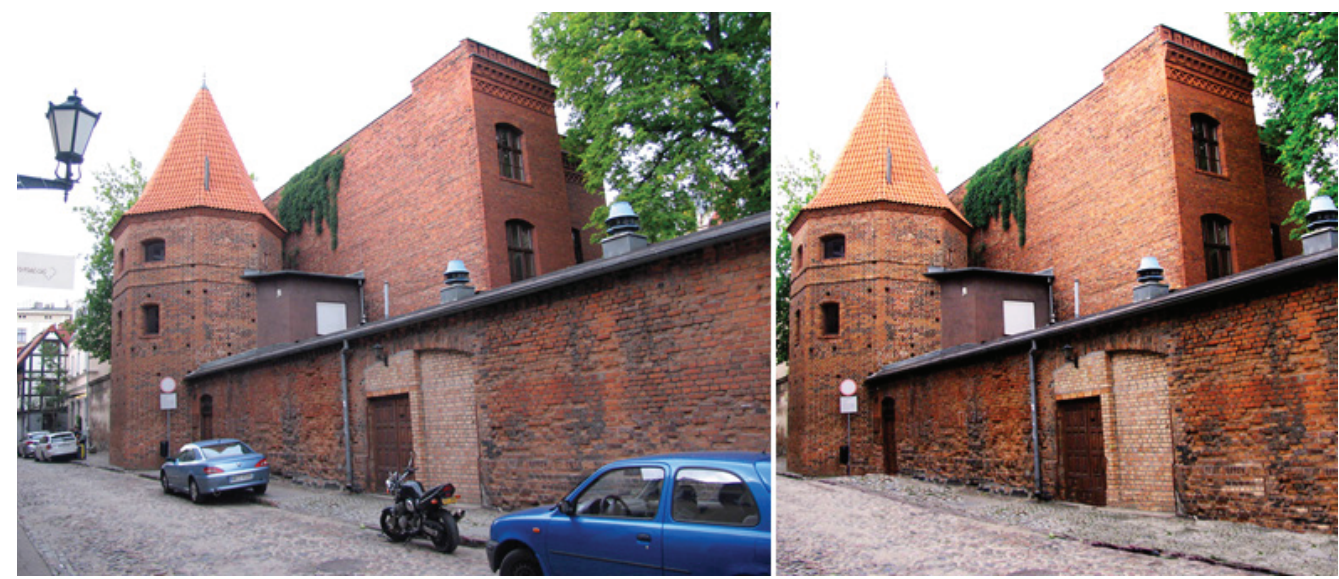

Fig. 1. Improving the appearance of photos Left: original photo. Right: final photo (source: own work) 

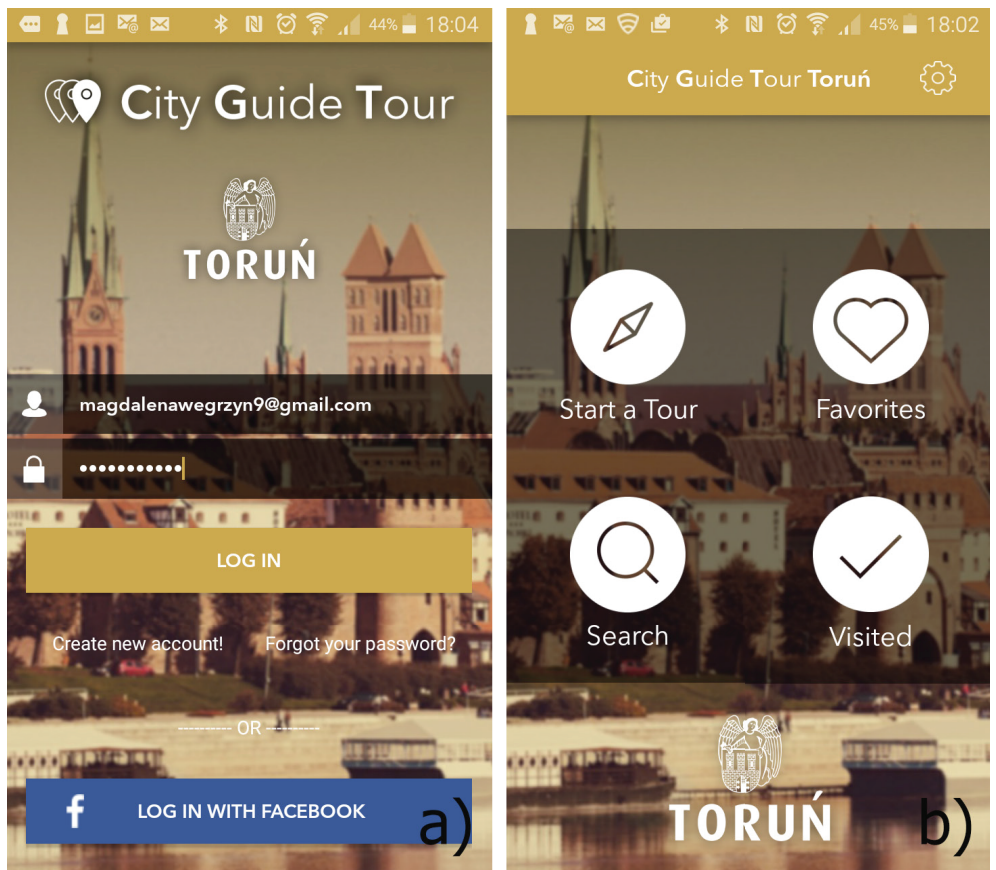

Fig. 2. Start window: a) login page, b) main menu (source: own work)

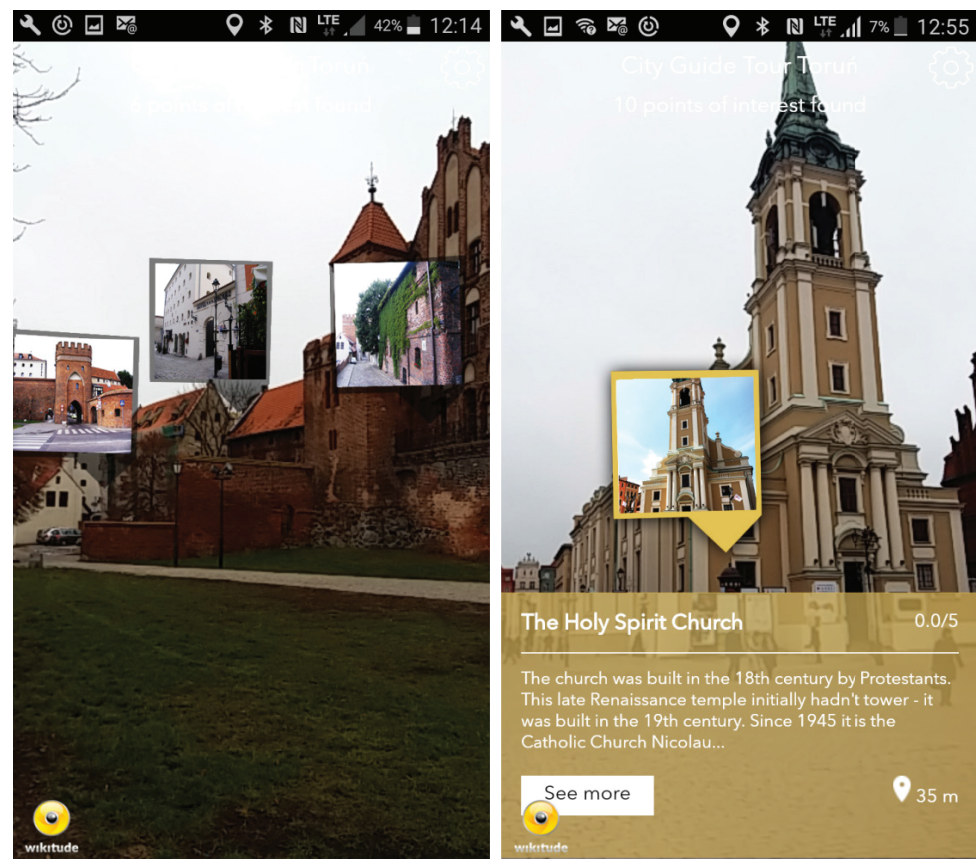

Fig. 3. Examples of POI labels (source: own work) 

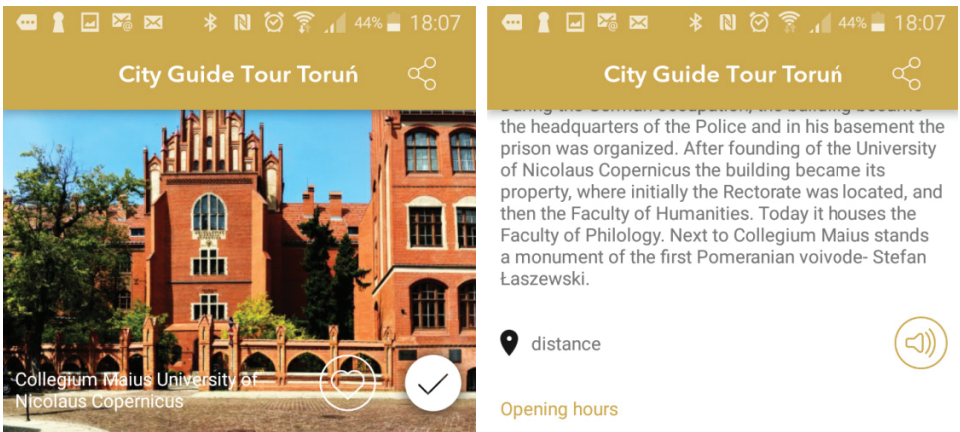

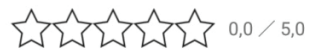

Opening hours

$24 \mathrm{H}$

The building was built in neo-Gothic style in 1907. Initially it housed the School of Crafts. During the First World War there was a field hospital, and in the interwar period, the Office of the Pomeranian province. During the German occupation, the building became the headquarters of the Police and in his basement the prison was organized. After founding of the University of Nicolaus Copernicus the building became its property, where initially the Rectorate was located, and then the Faculty of Humanities. Today it houses the Faculty of Philology. Next to Collegium Maius stands a monument of the first Pomeranian voivode- Stefan Łaszewski.

\section{Admissions}

normal: 0.00 PLN

reduced: $0.00 \mathrm{PLN}$

Free entrance

the Interior is not accessible for tourists

Address

Fosa Staromiejska 3

87-100 Toruń

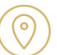

Fig. 4. Detailed information about the object (source: own work)

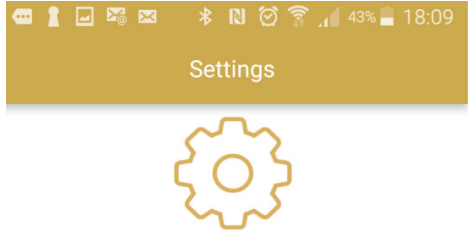

Setup your CityGuideTour

Tour distance: $1000 \mathrm{~m}$

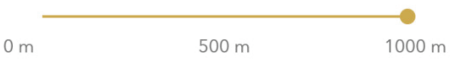

Language

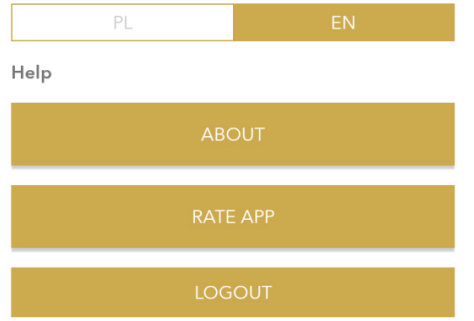

a)
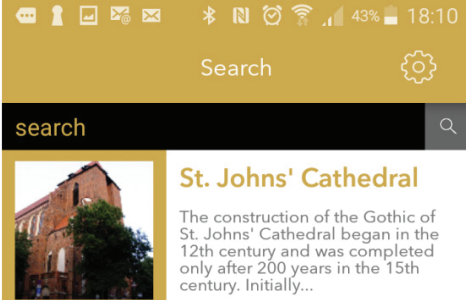

St. Johns' Cathedral

The construction of the Gothic of St. Johns' Cathedral began in the 12 th century and was completed century. Initially...
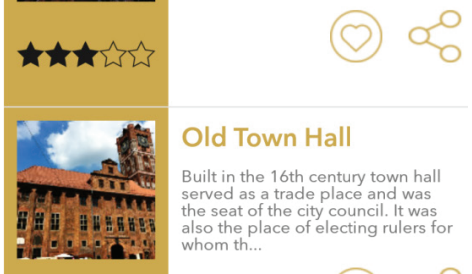

\section{Old Town Hall}

Built in the 16th century town hall served as a trade place and was the seat of the city council. It was whom th...
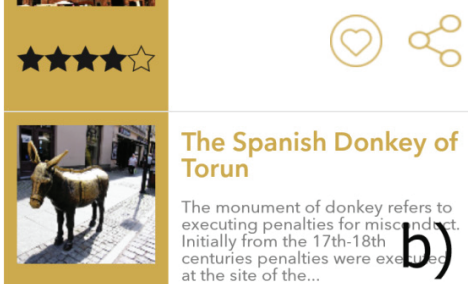

The Spanish Donkey of Torun

The monument of donkey refers to executing penalties for misc
Initially from the 17 th- 18 th centuries penalties
at the site of the

Fig. 5. Application view: a) change settings, b) list of objects (source: own work) 
Voice recordings are a very useful function. They present important information about the site and can be used by people with disabilities, as well as during tours inside buildings, where the tourists can freely admire the interior, and at the same time learn something about it.

Because the city of Torun is visited by more and more foreign tourists, data contained in the application as well as application interface were prepared in two language versions: Polish and English.

\section{Discussion}

During the CityGuideTour Torun application development, attention was paid to other applications operating on a similar principle. The principal feature distinguishing CityGuideTour from other products is its availability for a specific city. Many browsers like Wikitude and Layar products are universal, which means that they operate in almost any location. In addition, the CityGuideTour application does not offer the end users the possibility to edit or create their own layers. Another advantage of the resulting application is its clean interface and possibility of selecting the language of displayed data.

The use of the software in this project was not connected with any additional costs: all software was free or was obtained free of charge for the completion of this work. Additional costs were incurred only when visiting the test area, because the city of Torun is approximately $250 \mathrm{~km}$ from the author's place of residence. Field work lasted about five days, which is what contributed to the costs of travel and accommodation. Additionally, the costs associated with the purchase of paper maps and tourist guides, as well as tickets to the sites described should be taken into consideration. In conclusion, the total cost of the application development was not excessive.

During the work, it was assumed that the developed product would be introduced for public use; as such, it could not have any defects, and had to be fully functional. Therefore, emphasis was put on field testing the application. The study and analysis of the correct functioning of the application allowed the developers to detect and eliminate bugs. Moreover, sharing the product online is connected with the need to update it - to have a fully functional product, we should remember about changes due to factors such as changing ticket prices.

The final product can certainly contribute to the growth of tourism in Torun. Additionally, mobile applications are now easier and more popular for most tourists. Instead of buying multiple paper guides, users can download a modern tool with navigation and information about attractions for free. Moreover, the data in the application, in contrast to paper guides, can always be up to date.

There is no denying that no product is perfect. There are many changes or improvements that will facilitate the development of the application. CityGuideTour is a mobile tourist guide, which very much works properly; however, this does 
not mean that work related to the development of the application should be considered complete, because there are an infinite number of possibilities to extend $\mathrm{i}$ ts operation.

\section{Conclusion}

The development of technology means that it exerts a growing influence on human life. For most people, not using computers, the Internet, or mobile phones is inconceivable. With the rapid development of technology, mobile applications and information systems have become very popular. In recent years, applications using augmented reality have also quickly become popular in almost every field of life.

Today's navigation systems and mobile applications which allow the location of both the user and sites, are displacing analogue maps and traditional tourist guides. Undoubtedly, they facilitate visiting new places and have won the support of a wide audience. Therefore, the CityGuideTour Torun application supports the growth of tourism, the prevalence of AR technology, and above all, improving the exploration of the city.

The application created for the Polish city of Torun shows another face of tourism. Problems associated with finding attractions, lack of knowledge about the city or a long, unnecessary search for information about interesting places should not be part of the tourist experience. The only restriction in the use of the application is connected with hardware capabilities. In order to allow for the location of both the user and the site, a mobile device must have a GPS or GLONASS module, an electronic compass, an accelerometer and gyroscope. The presence of a digital camera is a requirement. Additionally, the device should have a high-speed graphics processor and network connection. Almost every smartphone already has these tools. Therefore, AR technology currently allows user to combine a recreational and practical function - the user not only obtains useful information, but also has the opportunity to learn through play.

\section{Acknowledgements}

The CityGuideTour Torun application was developed within the scope of the engineering thesis by Magdalena Węgrzyn, entitled "Development of a Tourist Application with the Use of Augmented Reality", carried out at the Faculty of Civil Engineering and Geodesy of the Military Technical Academy in Warsaw under the supervision of Albina Mościcka, PhD Eng. 


\section{References}

Aceti, L. (2013). Not Here, Not There: An Analysis of an International Collaboration to Survey Augmented Reality Art. Leonardo Electronic Almanac, 19(1), 5-8.

Alabaster, J. (2013). Pioneer launches car navigation with augmented reality, heads-up displays, http:// www.computerworld.com/article/2498299/personal-technology/pioneer-launches-car-navigationwith-augmented-reality--heads-up-displays.html accessible online: March 7, 2017

Azuma, R. T. (1997). A Survey of Augmented Reality. Teleoperators and Virtual Environments, 6 (4), 355-385.

Bielecka, E., Pokonieczny, K. and Kamiński, P. (2014). Study on spatial distribution of horizontal geodetic control points in rural areas. Acta Geodaetica et Geophysica, 49 (3), 357-368. DOI 10.1007/s40328-014-0056-6

Bryon, F. (2010). Myron Krueger Biography, http://thedigitalage.pbworks.com/w/page/22039083/ Myron\%20Krueger accessible online: March 7, 2017

Calka, B. and Cahan, B., (2016). Interactive map of refugee movement in Europe. Geodesy and Cartography, 65(2), 139-148. https://doi.org/10.1515/geocart-2016-0010

Donovan, J. (2012). Junaio Augmented Reality Browser Gets A UI Makeover, https://techcrunch. com/2012/06/20/junaio-augmented-reality-browser-gets-a-ui-makeover-video/ accessible online: March 7, 2017

Furht, B. (2011). Handbook of Augmented Reality. Springer Science \& Business Media.

Halik, Ł. (2012). New surveyor tool or superfluous gadget [In Polish: Nowe narzędzie geodety czy zbędny gadżet?]. Geodeta - magazyn geoinformacyjny,10 (209), 20-24.

James, P. (2015). Watch the 'Godfather of VR' Ivan Sutherland Speak at the 2015 Proto Awards. http:// www.roadtovr.com/watch-the-godfather-of-vr-ivan-sutherland-speak-at-the-2015-proto-awards/ accessible online: March 7, 2017

Kaczor, A. (2011). 40 Best Applications Using Augmented Reality on iOS [In Polish: 40 Najlepszych aplikacji wykorzystujących technologię Augumented Reality na iOS], http://myapple.pl/forums/ topic/154920-40-najlepszych-aplikacji-wykorzystuj\%C4\%85cych-technologi\%C4\%99-augumentedreality-na-ios/ accessible online: March 7, 2017

Kulka, I. (2012). "Follow Me" Augmented Reality Navigation, http://ael.gatech.edu/ mrdesignclass/2012/01/16/follow-me-augmented-reality-navigation/ accessible online: March 7, 2017

Langlotz, T., Grasset, R., Wagner, D., Mulloni, A. and Gruber, L. (2013). History of Mobile Augmented Reality, http://www.icg.tugraz.at/Members/langlotz/history-of-mobile-ar accessible online: March 7, 2017

Mościcka, A. and Wyszyński, K. (2016). How to combine historical and technical knowledge - master's level teaching experience. Proceedings of the 9th annual International Conference of Education, Research and Innovation, November 14-16, Seville (Spain), 3815-3824. DOI:10.21125/ iceri.2016.1903.

Rolland, J. P., Holloway, R. L. and Fuchs, H. (1994). A comparison of optical and video see-through head-mounted displays. Proceedings of SPIE - The International Society for Optical Engineering, Telemanipulator and Telepresence Technologies, Vol. 2351, 293-307. DOI: 10.1117/12.197322

Sutherland, I. (1968). A Head-Mounted Three Dimensional Display, AFIPS'68 Fall Joint Computer Conference, December 9-11, 1968, American Federation of Information Processing Societies, (pp. 757-764).

URL 1, History of Virtual Reality: http://www.vrs.org.uk/virtual-reality/history.html accessible online: March 7, 2017

URL 2, The father of Virtual Reality - Morton L. Heilig: http://www.mortonheilig.com/

URL 3, Official website of Layar technology developer: https://www.layar.com/ accessible online: March 7, 2017 
URL 4, Official website of Wikitude technology developer: http://www.wikitude.com/ accessible online: March 7, 2017

URL 5, Official website of PokemonGo application developers, http://www.pokemongo.com accessible online: March 7, 2017

URL 6, Official website of PanoramaScope application developers: http://panoramascope.com/ accessible online: March 7, 2017

URL 7: Official website of Wikitude Navigation application developer http://www.wikitude.com/ showcase/wikitude-navigation/ accessible online: March 7, 2017

URL 8, Official website of Audacity software, http://www.audacityteam.org/ accessible online: March 7, 2017

URL 9, Official website of Balabolka speech synthesizer developers, http://www.cross-plus-a.com/pl/ balabolka.htm accessible online: March 7, 2017

URL 10, Official website of EnviroSolutions company, http://www.envirosolutions.pl/ accessible online: March 7, 2017 
